\title{
Developing educational escape rooms for experiential entrepreneurship education
}

\author{
Author(s) \\ Martina, Richard A. ; Göksen, Sultan \\ DOl \\ 10.1177/2515127420969957 \\ Publication date \\ 2022 \\ Document Version \\ Author accepted manuscript (AAM) \\ Published in \\ Entrepreneurship Education and Pedagogy
}

Link to publication

Citation for published version (APA):

Martina, R. A., \& Göksen, S. (2022). Developing educational escape rooms for experiential entrepreneurship education. Entrepreneurship Education and Pedagogy, 5(3), 449-471.

https://doi.org/10.1177/2515127420969957

It is not permitted to download or to forward/distribute the text or part of it without the consent of the author(s) and/or copyright holder(s), other than for strictly personal, individual use, unless the work is under an open content license (like Creative Commons).

If you believe that digital publication of certain material infringes any of your rights or (privacy) interests,

please let the Library know, stating your reasons. In case of a legitimate complaint, the Library will make the material inaccessible and/or remove it from the website. Please contact the library:

https://www.amsterdamuas.com/library/contact/questions, or send a letter to: University Library (Library of the University of Amsterdam and Amsterdam University of Applied Sciences), Secretariat, Singel 425, 1012 WP Amsterdam, The Netherlands. You will be contacted as soon as possible. 


\section{Developing Educational Escape Rooms for Experiential Entrepreneurship Education}

\section{Introduction}

Educational escape rooms (EERs) are increasingly used in higher education as learning innovations that focus on learning through student collaboration (Clarke et al., 2017). The games consist of one or more puzzles. Students collaborate on solving these puzzles and complete the EER when they 'escape' out of the room. To solve the puzzles, students have to make use of knowledge and skills that are offered in their educational programs. Educational escape rooms are also referred to as non-digital forms of game-based learning (GBL). The latter entails the use of complete games such as computer simulations for educational purposes (Deterding et al., 2011). A cause for the proliferation of EERs in higher education is their capacity to positively influence student motivation (Fotaris \& Mastoras, 2019). Whereas other forms of GBL fail to enhance student motivation (Wouters et al., 2013), due to EERs’ physical and adventurous characteristics (Jambhekar et al., 2019), they acquire the attention of the students (i.e., a key antecedent to student motivation [Keller, 1987]).

Educational escape rooms are common in educational fields where skills developments are central such as Science, Technology, Engineering, and Mathematics (STEM) subjects and healthcare (cf. Rosenkrantz et al., 2019; Williams, 2018). However, despite the importance of skills in entrepreneurship (cf. Michelacci, 2003; Smith et al., 2007), the vital role of serious games and simulations within general entrepreneurship education (EE), and the benefits of EERs to foster student motivation (Fotaris \& Mastoras, 2019), EERs are marginally implemented in EE mainly due to a lack of evaluated design elements to guide their creation. 
Therefore, the purpose of the study was to evaluate design elements (Göksen et al., 2019) for EERs to facilitate the adoption of these learning innovations in experiential EE. We focus our study on experiential EE because EERs are especially well suited to experiential learning (Bellotti et al., 2013). We used a research-through-design approach (Romme \& Reymen, 2018) and created an EER based on 11 design elements derived from the literature on social cognitive theory, entrepreneurship competences, and gamification. We evaluated the EER in two cycles with two diverse groups of Bachelor's students at a university of applied sciences in the Netherlands. By presenting evaluated design elements for EERs, we are contributing to the literature and practice of experiential EE. We show which design elements work well and which do not. Educational professionals can implement the comprehensively designed EER we present in their experiential EE programs.

\section{Educational Escape Rooms}

Educational escape rooms are "live-action team-based games where players discover clues, solve puzzles, and accomplish tasks in one or more rooms in order to accomplish a specific goal (usually escaping from the room) in a limited time” (Nicholson, 2015, p.1). Live-action means that the players engage directly with the game world (Nicholson, 2018). Educational escape rooms are part of the growing use of educational games, also referred to as game-based learning (GBL), but specifically non-digital GBL (Clarke et al., 2017). Game-based learning is appropriate for encouraging learning as it allows learners to simulate regular learning through play, creating individual learning processes (Neck et al., 2014). It also stimulates learning through cognition (Vogel et al., 2006) and learning by doing (Bellotti et al., 2014). Game-based learning is suitable for experiential EE (Neck \& Greene, 2011), as research shows that it 
positively influences entrepreneurial intention and the behavior of students (Fellnhofer, 2015). It also aids students in acquiring an entrepreneurial mindset and skills (La Guardia et al., 2014).

The development of escape rooms dates back to 2007 in Japan, where they were implemented for commercial purposes. Since first being introduced to the U.S. in 2013, they have experienced fast growth in popularity (Nicholson, 2015). The popularity of commercial escape rooms has carried over to education, especially in STEM subjects.

Due to their capacity to positively influence student motivation (Fotaris \& Mastoras, 2019), and promote collaboration in learning (Wiemker et al., 2015), EERs are increasingly used in higher education, mainly in disciplines that require skills development to solve real-world problems such as STEM subjects and healthcare. For example, EERs are used for teaching teamwork skills (e.g., shared goal-setting) to undergraduate STEM students (cf. Williams, 2018), programming skills (e.g., applying JavaScript functions) to Bachelor's students majoring in Telematics (cf. Lopez-Pernas et al., 2019), non-technical skills (e.g., recognizing and understanding contexts) to Bachelor's students in emergency medicine (cf. Rosenkrantz et al., 2019), radiology skills (e.g., diagnosis of tumors) to graduate radiology students entering residency (cf. Jambhekar et al., 2019), and strategic management and leadership skills to Ph.D. students in healthcare (cf. Franco \& DeLuca, 2019). The professionals working in these disciplines are less preoccupied with the development of abstract knowledge that explains the world, and more engaged in how abstract knowledge facilitates the design of practical solutions to problems (Schön, 2017). A tacit understanding of the practice and procedural knowledge (Vincenti, 1990) is vital in designing solutions for practice, two elements that form part of EERs. 
Entrepreneurship shows similarities to the STEM subjects and healthcare fields as entrepreneurs also design solutions (e.g., products, firms, and markets) (Sarasvathy, 2003) to real-world problems (Dimov, 2016). A well-known example is the Nobel laureate Prof. Muhamad Yunus who created the Grameen Bank to provide microloans to entrepreneurs who do not qualify for loans from traditional banks (Bayulgen, 2008). In addition, GBL, such as computer simulations, are well suited to foster learning in EE (Fox et al., 2018). Thus, EERs are appropriate for skills development through EE.

However, there is a lack of EERs in EE. This lack remains despite the importance of skills in entrepreneurship (cf. Michelacci, 2003; Smith et al., 2007) and the benefits of EERs for fostering student motivation (Fotaris \& Mastoras, 2019). Furthermore, contemporary EE draws on the concepts of praxis, action, experience, and reflection (Hägg \& Kurczewska, 2016). These concepts are also central in EERs (Veldkamp et al., 2020). Hence, EERs are suitable for experiential EE (Bellotti et al., 2013). Experiential learning requires students to apply selfregulation and take responsibility for learning (Von Glasersfeld, 1987). Educational escape rooms permit students to exercise these behaviors when playing the games. Therefore, in this study, we limit our focus to experiential EE.

One reason for the lack of EERs in experiential EE is the lack of evaluated guidelines for creating them. Since EERs are live-action games, it is necessary to merge design elements of experiential learning, entrepreneurship competences, and GBL, which proves to be a daunting task.

The Theories Underpinning Educational Escape Rooms for Experiential Entrepreneurship Education 
To evaluate the design principles for EERs, we follow Göksen et al. (2019) and rely on the social cognitive theory (Bandura, 1986, 2001) and entrepreneurship competences framework (Bacigalupo et al., 2016). The social cognitive theory suggests that learning does not take place only cognitively, but is an interaction between the learner's person, behavior, environment- the Triadic Reciprocal Determinism (TRD) (Bandura, 1978). The social cognitive theory also suggests that the learning process contains four interrelated components: attentional, retention, motor production, and motivation (Bandura, 1977). In contrast to behavioral theories of learning, the social cognitive theory suggests that learning can also occur through observation.

The social cognitive theory is well suitable for EE and EERs. Its fundamental concepts in the TRD have been frequently the subject of research in entrepreneurship in general and EE (Winkler, 2013). For example, a key concept within the TRD is self-efficacy- an individual's belief in his/her ability (Bandura, 1977). Self-efficacy is formed through an individual's mastery experiences, vicarious experiences, verbal persuasion, and psychological states (Bandura, 1977), and entrepreneurial self-efficacy has been found to influence entrepreneurial intention, opportunity recognition, and goal commitment (Newman et al., 2019). Research also suggests that EERs can positively influence their participants' self-efficacy (Diemer et al., 2019). Furthermore, mastery and vicarious experiences are the essence of EERs as students take action to solve puzzles and also observe the action of their peers.

A framework for determining what should be (or is) learned is the entrepreneurship competence model (Béchard \& Grégoire, 2007). Entrepreneurship competences are the "underlying characteristics such as specific knowledge, motives, traits, self-images, social roles and skills which result in venture birth, survival and/or growth” (Mitchelmore \& Rowley, 2010, pp.96-97). The competences are formed as individuals interact with their environments (Morris 
et al., 2013) and thus can be considered to be central in EE (Neck \& Corbett, 2018). There is no consensus on what competences entrepreneurs should possess. However, the competences are commonly divided between those competences related to human behavior (e.g., interpersonal skills, motivation, productive thinking, and leadership [RezaeiZadeh et al., 2017]) and those related to content areas (e.g., finance, marketing, and management [Bellotti et al., 2014]). There are also specific competences for what are considered entrepreneurial activities (e.g., environmental scanning, spotting opportunities, and idea generation [Mitchelmore \& Rowley, 2010]). Considering that the purpose of entrepreneurship competences is to realize opportunities, they are also grouped into three main domains: 1) ideas \& opportunities (i.e., spotting valuable opportunities), 2) resources (i.e., mobilization of oneself and resources), and 3) into action (i.e., taking action to exploit opportunities) (Bacigalupo et al., 2016).

\section{The Design Elements of Educational Escape Rooms for Experiential Entrepreneurship}

\section{Education}

Göksen et al. (2019) formulated 11 design elements that should be developed in an EER for the entrepreneurship competences and for the gameplay to qualify as a non-digital GBL (see Table 1 for an overview). The first five design elements relate to the entrepreneurship competences that Göksen et al. (2019) judged as necessary to be entrepreneurial. First, solving real-world problems requires cooperation among individuals (Weber \& Khademian, 2008) since no single individual possesses all the resources to progress alone through the entrepreneurial process. Entrepreneurship is a social process (Engel et al., 2017), and the successes of entrepreneurial firms are influenced by their cooperative strategies (Dowling \& Helm, 2006). In addition, cooperation among individuals is viewed as one of the primary skills 
of expert entrepreneurs (Sarasvathy, 2001). Therefore, EERs should be designed to require cooperation among the students.

Second, opportunities are the essence of entrepreneurship (Shane \& Venkataraman, 2000; Short et al., 2010). Sarasvathy et al. (2010) suggest three types of opportunities: 1) allocation opportunities (i.e., matching an existing demand with an existing supply), 2) discovery opportunities (i.e., matching supply and demand where one of the two does not yet exist and must be discovered), and 3) creation opportunities (i.e., creating a demand and supply where neither exists yet). Hence, to be entrepreneurial, individuals must have the competence to discern the type of opportunity, in order to determine which process and behavior are required. These skills are considered essential for entrepreneurs (Bacigalupo et al., 2016).

Third, the entrepreneurship competences are seen as transversal skills, i.e., the application of skills outside of the context in which the skill has been acquired (Bacigalupo et al., 2016). In other words, individuals should be able to apply entrepreneurship competences under different conditions, such as starting new ventures (Gartner, 1985) or within existing organizations (Antoncic \& Hisrich, 2001, 2003). Self-awareness (i.e., awareness of your needs, aspiration, wants, strengths and weaknesses [Bacigalupo et al., 2016]) and self-efficacy (i.e., belief in your abilities [Bandura, 1977]) are required to apply skills in new contexts. Therefore, they should be included as design elements of an EER.

Fourth, showing initiative and having motivation and perseverance are also essential entrepreneurship competences. The defining characteristic of the entrepreneurial process is uncertainty (McMullen \& Shepherd, 2006). Entrepreneurs initiate a process with uncertainty, and with every decision and action, entrepreneurs reduce the uncertainty into risks. As the responses required in events and the consequences of the responses are not always clear 
(Milliken, 1987), the entrepreneurial process is characterized by setbacks. Taking adequate initiatives (Townsend et al., 2018), perseverance (Markman et al., 2003), and motivation (Shane et al., 2003) are all essential for dealing with the setbacks.

Fifth, considering that entrepreneurship entails transformations (Sarasvathy \& Dew, 2005) and transactions (Michael, 2007), assessing financial investments is crucial to be entrepreneurial (Martina, 2019). Therefore, financial and economic literacy (Bacigalupo et al., 2016) are included as design elements for EERs.

The other six design elements relate to the gameplay, i.e., the patterns in which players interact with a game (Salen, Tekinbas \& Zimmerman, 2003). They are required to create the adventurous and game-like characteristics of an EER. First, an EER should include a narrative to delineate the context (O’Donovan et al., 2013). Second, puzzles of increasing difficulty are required to keep challenging the students and avoid discouragement (Ericsson, 2008). Third, there should be immediate feedback aids to keep students engaged in the game (Nah et al., 2014). Fourth, hints should be included to coach students in attaining new skills (Lopez-Pernas et al., 2019). Fifth, a time limit and countdown clock are required to create a sense of urgency from the students (Kapp, 2012). Finally, game rules are needed (Jambhekar et al., 2019) so students know which behaviors are permitted and so that the EER can be played fairly.

--- Insert Table 1 about here---

In summary, we evaluated the 11 design elements for EERs in experiential EE (Göksen et al., 2019) using a research-through-design approach (Romme \& Reymen, 2018). We explain the approach below. 


\section{Methods}

\section{Research strategy}

In this study, we used a research-through-design approach (Romme \& Reymen, 2018).

Developed initially in design sciences to understand how designers create artifacts, this approach has also been recently used in educational sciences (Collins, 1992) to develop design elements that, when applied, lead to desired outcomes (van Aken, 2004). The research-through-design is suitable for this study as we aim to evaluate the design elements of EERs. The main motive is to develop actionable knowledge that educational professionals can apply to develop EERs. We implemented the approach by iterating between the creation and evaluation stages through two cycles (i.e., a pilot EER and an actual EER), which were one month apart.

\section{Participants}

The EER was designed for first-year Bachelor’s students of marketing at a university of applied sciences based in the Netherlands. The pilot EER was evaluated with 12 first-year students from the Bachelor's degree program in secondary education majoring in economics at the same university. This group was ideal for the pilot since the knowledge domains of the two groups overlap (Vereniging Hogescholen, 2017a, 2017b).

The EER was an initiative from IXAnext ${ }^{1}$ and commissioned by the Department of Marketing at the Faculty of Business and Economics. The students had applied for a specialization in entrepreneurship within the marketing program. The primary motivation of the faculty for using

\footnotetext{
${ }^{1}$ Innovation Exchange Amsterdam (IXA) is the expert interface between Amsterdam-based universities and parties interested in their research findings and knowledge, such as companies, educational institutions, investors, health care providers, entrepreneurs, government bodies and societal organizations.
} 
an EER was to offer students an engaging activity to improve their entrepreneurial skills through collaborating with their future classmates. Twenty-four first-year Bachelor's students of marketing took part in the EER.

\section{Evaluating the Educational Escape Room}

For the pilot EER, the students were randomly divided into four teams of three students, and each team was assigned a supervising coach. We randomly divided the students into teams to minimize the influence of systematic differences between the teams (e.g., average age, gender, skills, and familiarity with one another) in terms of how students interact with the EER. The supervisory coaches were fourth-year students at the same university on the Bachelor of Teaching Training for Secondary Education, with a specialization in Economics. They were familiar with the EER design and helped make the physical puzzles of the EER, and thus were suitable to supervise the gameplay and provide hints where necessary. The students played the EER simultaneously in the same room. For the actual EER, the students were randomly divided into eight teams of three students, distributed over two rooms. Each team was also assigned a supervisory coach. These students also played the EER simultaneously.

All supervisory coaches were briefed and received instructions regarding the classroom setup, instructions for the students, and provision of hints (see Supplementary Material 1) a couple of days in advance of the EER. We used a standard classroom for the EER. The room was divided into four separate sections, each containing a table with the puzzles of the games. To prevent students from copying solutions to the puzzles from other teams, we individualized the solutions to puzzles. In other words, the puzzles from the different teams required different solutions. 
The EER aimed to offer the students an engaging activity to improve their entrepreneurial skills through collaboration with their (future) classmates. The EER started with a briefing. The students received instructions via video. Thereafter, the students were given 60 minutes to play the game(s) and to escape the room. Students could request hints from the supervisory coaches. After the EER was finished, a plenary debriefing took place where: 1) the students were given time to decompress, 2) we requested feedback about the gameplay from the students, 3) we presented the solutions to the puzzles, 4) we discussed the knowledge, skills, and attitude required in relation to the intended learning goals, and 5) we provided students feedback on their performances (Veldkamp et al., 2020). The debriefing was guided by the researchers and supported by the supervisory coaches and took between 15 and 20 minutes.

\section{Data collection}

For triangulation purposes, data were collected from three different sources (Yin, 2009) observation, a focus group with the supervisory coaches, and interviews with participants (interviews were done only after the actual EER). This triangulation ensured that the design elements for developing the EER were not explored through one lens, but rather a variety of lenses, which allowed for multiple facets of the phenomenon to be revealed and understood (Baxter \& Jack, 2008).

We used sheets to record the observations made during the games. For example, timesheets were used to record the time required for the teams needed to complete the games. We also conducted focus group interviews with the supervisory coaches to gain different perspectives on the EER (Dilorio et al., 1994). The discussions revolved around the coaches' experiences of the cooperation observed within the student teams (e.g., the division of labor to solve the puzzles), 
the level of difficulty of the puzzles (e.g., the time it took for teams to complete the games), the use of hints, and students' motivation.

Finally, for the actual EER, we also interviewed eight randomly selected students to gain a complete picture of their experiences during the EER (Boyce \& Neale, 2006). The interviews were conducted with one group member from each team, directly after the debriefing, and took place at quiet study spots at the university. In order to have the interviews directly after the EER, we prepared selected interviewers beforehand. All interviews were conducted simultaneously, so there were no interactions between the interviewees that might have affected the responses. The interviews followed a semi-structured approach and ranged from five to 20 minutes, taking nine minutes on average. The interview questions were adapted from Clarke et al. (2017), who studied EER design and evaluated the design in short evaluation interviews.

--- Insert Table 2 about here---

\section{Data analysis and evaluation}

We started the analysis with 'open coding' (Locke, 2001) to generate themes from the data. These themes were further reduced to design elements (Strauss \& Corbin, 1990). Finally, we compared the design elements induced from the data with the designed elements deduced from theory (Yin, 2009) to refine the design elements for EER. We did two iterations of this process, one after the pilot and one after the EER (see Table 3 for the iterations of the design elements throughout the study).

--- Insert Table 3 about here--- 


\section{Findings}

In this section, we describe the final version of the EER that was developed. We first describe the general contours of the EER (i.e., the design elements regarding the gameplay) followed by the details of the games (i.e., the design elements regarding the competences).

\section{The general contours of the game}

Narrative: The overall storyline for the EER was that students have applied for the specialization entrepreneurship within their educational program. In order to be permitted to the specialization, students had to prove that they met the minimum required entry (entrepreneurial) skills. These skills are evaluated through several job interview questions (i.e., the games), and the answers to the questions are the solution to the puzzles, completion of the games, and ‘escaping’ out of the room. Hence, every puzzle provided evidence of one (or more) entry (entrepreneurial) skills.

Increasing difficulty: The EER started with a relatively simple puzzle (i.e., the Global Goals) that matched the competence levels of the first-year Bachelor of Marketing at Dutch universities of applied sciences. As the EER progressed, the puzzles became increasingly difficult, requiring insights and competences developed in the second year of the Bachelor (see Supplementary Material 2 for an overview of the puzzles).

Immediate feedback: To solve the puzzles, students could try various solutions. The instant feedback that was provided to the students was whether their solutions solved the puzzles or not. 
Hint management: In addition to the immediate feedback provided by trying solutions to the puzzles, we provided hints on demand. We made a distinction between two hints: normal hints (i.e., providing a partial solution to a puzzle), and final hints (i.e., providing a complete solution to a puzzle). For each hint, the team received a penalty - two minutes for normal hints and 10 minutes for final hints (see Supplementary Material 2 for an overview of the hints). The hints were administered by the supervisory coaches. We also added hidden hints into the puzzles (e.g., a QR code that linked to a video showing the solution).

Time limit and countdown clock: The EER was designed to take 60 minutes. We used a digital countdown clock that was visible to all students to keep track of the time.

Game rules: In commercial escape rooms, the rules are communicated through instructional videos. We strived to replicate these escape rooms as much as possible by also communicating our rules through a video (see Supplementary Material 3). We adopted seven game rules:

1. Do not force or break the puzzles.

2. The uses of digital devices (e.g., laptops and mobile phones) and the Internet are not allowed except when instructed. Everything needed to solve the puzzles is in the room.

3. You are allowed to ask your assigned supervisory coach for hints, but you will be penalized: two minutes for normal hints and 10 minutes for final hints.

4. Be polite to each other and especially to your assigned supervisory coach. 
5. The supervisory coach can only address one student at a time. If he/she is busy, wait quietly for your turn.

6. You have 60 minutes to escape the room, so keep an eye on the time.

7. You can exit the room at any time, but if you leave before completing all the puzzles, you will lose.

The details of the game

The EER consists of a total of five games, each containing two or three parts, and each part containing one or more puzzles. The puzzles are the problems that should be solved (see Supplementary Material 2 for the overview of the games). All games contained a unique narrative that was aligned with the overall narrative of the EER. All games had the same objective, i.e., solve the puzzles and obtain the 4-digit code that unlocks the puzzles of the next game, and all games had to be solved in consecutive order. Furthermore, all games were designed to include the elements of cooperation, taking initiative, motivation and perseverance, and self-awareness and self-efficacy. The last part of the last game (no. 5) required cooperation between all the teams in the room. We describe the games and puzzles next (see Supplementary Materials $4-8$ for photos of the games and puzzles).

Game 1. The Global Goals: Entrepreneurship is not only making financial returns but also creating sustainable impact (Cohen \& Winn, 2007). The narrative of this game was that students should be able to spot issues relating to sustainability in order to enter the specialization. The design element included in this game is 'spotting opportunities' to connect the emojis with the right Global Goals. 
Game 2. The Balance Sheets: Financial literacy (Bacigalupo et al., 2016) and administration are essential. The latter provides insights into the financial position of a startup. The narrative of this game was that students should be able to administrate financial records in order to enter the specialization. The design element included in this game is 'financial and economic literacy' to balance the assets and financing.

Game 3. The Profit: In addition, the calculations of profits are crucial in order to make the right decisions regarding resource distribution. The narrative of this game was that students should be able to calculate the profit in order to enter the specialization. The design elements included in this game are 'financial and economic literacy' to determine the profit and 'spotting opportunities' to find the hidden numbers on the puzzles.

Game 4. Insights into the Market: Entrepreneurs need insights into market developments (Coviello \& Munro, 1995). The narrative of this game was that students should be able to see how seemingly disconnected events converge into market developments in order to enter the specialization. The design element included in this game is 'spotting opportunities' to find the hidden QR code to assemble a cube from loose pieces.

Game 5. Creativity: Entrepreneurship involves recognizing, creating, and exploiting opportunities (Davidsson, 2015) by creating novel solutions (Ward, 2004) with the resources available (Baker \& Nelson, 2005). The narrative of this game was that students should be able to use the materials they were given to generate creative solutions. The design element included in 
this game is 'spotting opportunities' to realize the link between a sandwich bag, a cork in a wine bottle, and a UV pen.

\section{Discussion and Contribution}

In this study, we evaluated 11 design elements (Göksen et al., 2019)—five related to entrepreneurship competences (cooperation; spotting opportunities; self-awareness and selfefficacy; initiative, motivation and perseverance; and financial and economic literacy) and six related to gameplay (narrative; increasing difficulty; immediate feedback; hint management; time limit and countdown clock; game rules)—for the creation of EERs in experiential EE. Next, we discuss which design elements worked well and which need further improvements.

The design elements that worked well

In general, the combination of the design elements regarding the entrepreneurship competences and the gameplay is well suited for EER in experiential EE. First, the students cooperated when playing the games. The puzzles were divided among the students in the teams, as each contributed to solving a part of the game. Hence, cooperation is well suited for EER. Second, all students remained engaged in the EER until the end. Although none of the teams completed the EER and escaped the room before they ran out of time, all teams reached the final game, and the students were continuously working on the puzzles. This behavior shows that

puzzles of increasing difficulty (Ericsson, 2008) and with immediate feedback (Nah et al., 2014) did not discourage the students. It also showed that the students remained motivated and persevered despite marginal success with the EER. Third, students also took initiatives to lead their teams. In two situations, the leadership role was divided between two students. Finally, 
although observing if the students have shown self-awareness and self-efficacy is difficult, the fact that they remain engaged, did not give up and solved the puzzles are signs that they used the competences.

The design elements needing improvements

There are five design elements that need to be reconsidered for EERs in experiential EE. First, although students generally took initiatives and leadership roles, on a few occasions other students experienced difficulties showing initiative. Thus, assertiveness should also be considered as a design element for EERs in experiential EE. Second, another difficulty experienced during the pilot and actual EER was the time limit. During the pilot, none of the teams were able to finish the EER within the allotted 60 minutes. Based on this observation, the EER was modified. We made the games easier by reducing the number of puzzles in the games. For example, we reduced the puzzles in Game 2 from 13 to nine (see Supplementary Material 2). Third, we also made slight changes to the hints management. We added hidden hints in the games to reduce difficulty. For example, in Game 4, we stuck a QR code on the bottom of the game box that directed to an instruction video of how to solve the puzzle. These changes allowed us to reduce the time pressure without sacrificing the content and links to the competencies addressed in the EER. Despite our efforts, during the actual EER, none of the students were able to complete all the games. Students experienced the EER as difficult due to a lack of time. For example, student 6 stated, "I found it a bit harder than I thought it would be for an escape room because we did not get out of it... it was not difficult, but it takes a lot of time." In addition, students were reluctant to ask for hints, despite increasing time pressures. Therefore, we advise 
providing the first hint without penalties so that students can become familiar with their team members and the EER.

Fourth, it is challenging to observe if the students actively seek opportunities. This challenge can be mitigated by adding additional hints or tools that can be used to solve the puzzles in the room. In this matter, the 'spotting opportunities' behavior can be observed if/when students move around the room to explore for hints and tools. Finally, although we explicitly asked students to treat the puzzles with care (i.e., game rule no. 1), some puzzles were broken. Therefore, attention must be paid to the durability of the puzzles.

\section{Some additional considerations}

We want to advance three additional considerations. First, we divided each game into two or more parts that provided partial solutions to the game. This strategy proved to be successful for encouraging cooperation among the students, especially positive interdependence. Game-based learning in which multiple students play a game is well suited to strengthen positive interdependence (Romero et al., 2012). However, although team formation consisting of a maximum of four students is promoted in education, we observed that the teams consisting of three and four students had difficulties solving the games quickly, especially the games that contained more than two puzzles. Second, the success of an EER depends on well-integrated game design elements such as the narrative, increasing difficulty of the puzzles, immediate

feedback, hint management, and time limit. Therefore, evaluating the EER is essential (LopezPernas et al., 2019). Finally, we designed the EER as a non-graded and formative activity. Nevertheless, the students were very motivated to participate in the EER, especially due to its competitive element. 


\section{Conclusion}

Educational escape rooms are increasingly used in education as learning innovations in STEM subjects and healthcare but to a lesser extent in EE. In this study, we evaluated design elements to facilitate the creation of EERs for experiential EE. Developing learning innovations is not without challenges. We identified three limitations to our study. First, the EER can mainly be used for experiential EE for first-year Bachelor's students of general business programs at Dutch universities of applied sciences. Therefore, we suggest evaluating the EER in other educational contexts, such as non-business programs and other countries.

Second, creating EER is challenging and time-consuming. The developers have to create the design elements, but also physically construct the puzzles. Thus, the creation of EER requires competences. We limited this study to the design elements that should be embedded within the EER. Future research should also study which competences educational professionals require to develop EER.

Finally, the solutions to the puzzles of the created EER are fixed. In other words, each puzzle has only one solution, and thus the outcomes of the cognitive processes are defined. It can be argued that this characteristic of the created EER is more aligned with managerial thinking (vs. entrepreneurial thinking.

In this study, we have laid the groundwork for EERs in experiential EE. It benefits experiential EE in several ways, such as fostering the acquisition of student attention, promoting student motivation, and sustaining entrepreneurial skills development. Therefore, we hope that this study facilitates the adoption of EERs in experiential EE. 


\section{References}

Aken, J. E. van. (2004). Management Research Based on the Paradigm of the Design Sciences: The Quest for Field-Tested and Grounded Technological Rules. Journal of Management Studies, 41(2), 219-246. https://doi.org/10.1111/j.1467-6486.2004.00430.x

Antoncic, B., \& Hisrich, R. D. (2001). Intrapreneurship: Construct refinement and cross-cultural validation. Journal of Business Venturing, 16(5), 495-527. https://doi.org/10.1016/S08839026(99)00054-3

Antoncic, B., \& Hisrich, R. D. (2003). Clarifying the intrapreneurship concept. Journal of Small Business and Enterprise Development, 10(1), 7-24.

https://doi.org/10.1108/14626000310461187

Bacigalupo, M., Kampylis, P., Punie, Y., \& Van den Brande, G. (2016). EntreComp: The entrepreneurship competence framework. In Publication Office of the European Union.

Baker, T., \& Nelson, R. E. (2005). Creating Something from Nothing: Resource Construction through Entrepreneurial Bricolage. Administrative Science Quarterly, 50(3), 329-366. https://doi.org/10.2189/asqu.2005.50.3.329

Bandura, A. (1977). Self-efficacy: Toward a unifying theory of behavioral change. Psychological Review, 84(2), 191-215. https://doi.org/10.1037/0033-295X.84.2.191

Bandura, A. (1978). The self system in reciprocal determinism. American Psychologist, 33(4), 344-358. https://doi.org/10.1037/0003-066X.33.4.344

Bandura, A. (1986). Social Foundations of Thought and Action: A Social Cognitive Theory. Englewood Cliffs, NJ: Prentice Hall.

Bandura, A. (2001). Social Cognitive Theory: An Agentic Perspective. Annual Review of Psychology, 52(1), 1-26. https://doi.org/10.1146/annurev.psych.52.1.1 
Baxter, P., \& Jack, S. (2008). Qualitative Case Study Methodology: Study Design and Implementation for Novice Researchers. The Qualitative Report, 13(4), 544-559.

Bayulgen, O. (2008). Muhammad Yunus, Grameen Bank and the Nobel Peace Prize: What Political Science Can Contribute to and Learn From the Study of Microcredit. International Studies Review, 10(3), 525-547. https://doi.org/10.1111/j.1468-2486.2008.00803.x

Béchard, J., \& Grégoire, D. (2007). Archetypes of pedagogical innovation for entrepreneurship in higher education: model and illustrations. In A. Fayolle (Ed.), Handbook of Research in Entrepreneurship Education: A general perspective (Vol. 1, pp. 261-284).

Bellotti, F., Berta, R., De Gloria, A., Lavagnino, E., Antonaci, A., Dagnino, F., ... Mayer, I. S. (2014). Serious games and the development of an entrepreneurial mindset in higher education engineering students. Entertainment Computing, 5(4), 357-366. https://doi.org/10.1016/j.entcom.2014.07.003

Bellotti, Francesco, Kapralos, B., Lee, K., Moreno-Ger, P., \& Berta, R. (2013). Assessment in and of serious games: An overview. Advances in Human-Computer Interaction, Vol. 2013. https://doi.org/10.1155/2013/136864

Boyce, C., \& Neale, P. (2006). Conducting in-depth interviews: A guide for designing and conducting in-depth interviews for evaluation input. Watertown, MA: Pathfinder International.

Bryant, P. (2006). Improving entrepreneurial education through self-regulatory skills. The NCIIA, 279-289.

Clarke, S. J., Peel, D. J., Arnab, S., Morini, L., Keegan, H., \& Wood, O. (2017). EscapED: A Framework for Creating Educational Escape Rooms and Interactive Games to For Higher/Further Education. International Journal of Serious Games, 4(3). 
https://doi.org/10.17083/ijsg.v4i3.180

Cohen, B., \& Winn, M. I. (2007). Market imperfections, opportunity and sustainable entrepreneurship. Journal of Business Venturing, 22(1), 29-49. https://doi.org/10.1016/j.jbusvent.2004.12.001

Collins, A. (1992). Toward a Design Science of Education. In New Directions in Educational Technology (pp. 15-22). https://doi.org/10.1007/978-3-642-77750-9_2

Coviello, N. E., \& Munro, H. J. (1995). Growing the entrepreneurial firm. European Journal of Marketing, 29(7), 49-61. https://doi.org/10.1108/03090569510095008

Davidsson, P. (2015). Entrepreneurial opportunities and the entrepreneurship nexus: A reconceptualization. Journal of Business Venturing, 30(5), 674-695. https://doi.org/10.1016/j.jbusvent.2015.01.002

Deterding, S., Dixon, D., Khaled, R., \& Nacke, L. (2011). From game design elements to gamefulness: Defining “gamification.” Proceedings of the 15th International Academic MindTrek Conference: Envisioning Future Media Environments, MindTrek 2011, 9-15. https://doi.org/10.1145/2181037.2181040

Diemer, G., Jaffe, R., Papanagnou, D., Zhang, X. C., \& Zavodnick, J. (2019). Patient Safety Escape Room: A Graduate Medical Education Simulation for Event Reporting. MedEdPORTAL, 15(1), 10868. https://doi.org/10.15766/mep_2374-8265.10868

Dilorio, C., Hockenberry-Eaton, M., Maibach, E., \& Rivero, T. (1994). Focus groups: an interview method for nursing research. The Journal of Neuroscience Nursing : Journal of the American Association of Neuroscience Nurses, Vol. 26, pp. 175-180. https://doi.org/10.1097/01376517-199406000-00013

Dimov, D. (2016). Toward a Design Science of Entrepreneurship. 
https://doi.org/10.1108/S1074-754020160000018001

Dowling, M., \& Helm, R. (2006). Product development success through cooperation: A study of entrepreneurial firms. Technovation, 26(4), 483-488.

https://doi.org/10.1016/j.technovation.2005.06.015

Engel, Y., Kaandorp, M., \& Elfring, T. (2017). Toward a dynamic process model of entrepreneurial networking under uncertainty. Journal of Business Venturing, 32(1), 35-51. https://doi.org/10.1016/j.jbusvent.2016.10.001

Ericsson, K. A. (2008). Deliberate Practice and Acquisition of Expert Performance: A General Overview. Academic Emergency Medicine, 15(11), 988-994. https://doi.org/10.1111/j.1553-2712.2008.00227.x

Fellnhofer, K. (2015). Changing entrepreneurial intention and behaviour: A digital game-based learning environment dedicated to entrepreneurship education . Journal for International Business and Entrepreneurship Development, 8(4), 378-404.

Fotaris, P., \& Mastoras, T. (2019). Escape Rooms for Learning: A Systematic Review. ECGBL 2019 13th European Conference on Game-Based Learning, 235.

Fox, J., Pittaway, L., \& Uzuegbunam, I. (2018). Simulations in Entrepreneurship Education: Serious Games and Learning Through Play. Entrepreneurship Education and Pedagogy, 1(1), 61-89. https://doi.org/10.1177/2515127417737285

Franco, P. F., \& DeLuca, D. A. (2019). Learning Through Action: Creating and Implementing a Strategy Game to Foster Innovative Thinking in Higher Education. Simulation \& Gaming, 50(1), 23-43. https://doi.org/10.1177/1046878118820892

Gartner, W. B. (1985). A conceptual framework for describing the phenomenon of New Venture Creation. Academy of Management Review, 10(4), 1-11. 
https://doi.org/10.5465/amr.1985.4279094

Göksen, S., Martina, R. A., \& Sormani, E. (2019). Exploring the Design Elements for Developing Educational Escape Rooms for Experiential Entrepreneurship Education. In T. Baaken, P. Buła, K. Kurzhals, \& H. Lyszczarz (Eds.), Management Sciences and Future Challenges. Festschrift anlässlich des 30jährigen Jubiläums der Kooperation der Wirtschaftsuniversität Krakau und der Fachhochschule Münster (pp. 161-173). Cracow Munster.

Hägg, G., \& Kurczewska, A. (2016). Connecting the dots: A discussion on key concepts in contemporary entrepreneurship education. Education and Training, 58(7-8), 700-714. https://doi.org/10.1108/ET-12-2015-0115

Jambhekar, K., Pahls, R. P., \& Deloney, L. A. (2019). Benefits of an Escape Room as a Novel Educational Activity for Radiology Residents. Academic Radiology. https://doi.org/10.1016/j.acra.2019.04.021

Kapp, K. M. (2012). The Gamification of Learning and Instruction: Game-based Methods and Strategies for Training and Education. Retrieved from https://www.wiley.com/en-us/The+Gamification+of+Learning+and+Instruction \%3A+Game+based+Methods+and+Strategies+for+Training+and+Education-p9781118096345

Keller, J. M. (1987). Development and use of the ARCS model of instructional design. Journal of Instructional Development, 10(3), 2-10. https://doi.org/10.1007/BF02905780

La Guardia, D., Gentile, M., Dal Grande, V., Ottaviano, S., \& Allegra, M. (2014). A Game based Learning Model for Entrepreneurship Education. Procedia - Social and Behavioral Sciences, 141, 195-199. https://doi.org/10.1016/j.sbspro.2014.05.034 
Locke, K. (2001). Grounded theory in management research. Thousand Oaks, CA: SAGE

Lopez-Pernas, S., Gordillo, A., Barra, E., \& Quemada, J. (2019). Examining the Use of an Educational Escape Room for Teaching Programming in a Higher Education Setting. IEEE Access, 7, 31723-31737. https://doi.org/10.1109/ACCESS.2019.2902976

Markman, G. D., Baron, R. A., \& Balkin, D. B. (2003). The Role of Regretful Thinking, Perseverance, and Self-Efficacy. Advances in Entrepreneurship, Firm Emergence and Growth, Vol. 6, pp. 73-104. https://doi.org/10.1016/S1074-7540(03)06004-5

Martina, R. A. (2019). Toward A Theory of Affordable Loss. Small Business Economics. https:// doi.org/doi:10.1007/s11187-019-00151-y

McMullen, J. S., \& Shepherd, D. A. DA. (2006). Entrepreneurial action and the role of uncertainty in the theory of the entrepreneur. Academy of Management Review, 31(1), 132152. https://doi.org/10.5465/AMR.2006.19379628

Newman, A., Obschonka, M., Schwarz, S., Cohen, M., \& Nielsen, I. (2019, February 1). Entrepreneurial self-efficacy: A systematic review of the literature on its theoretical foundations, measurement, antecedents, and outcomes, and an agenda for future research. Journal of Vocational Behavior, Vol. 110, pp. 403-419. https://doi.org/10.1016/j.jvb.2018.05.012

Michael, S. C. (2007). Transaction cost entrepreneurship. Journal of Business Venturing, 22(3), 412-426. https://doi.org/10.1016/J.JBUSVENT.2006.04.005

Michelacci, C. (2003). Low Returns in R\&amp;D due to the Lack of Entrepreneurial Skills. The Economic Journal, 113(484), 207-225. https://doi.org/10.1111/1468-0297.00095

Milliken, F. J. (1987). Three Types of Perceived Uncertainty About the Environment: State, Effect, and Response Uncertainty. Academy of Management Review, 12(1), 133-143. 
https://doi.org/10.5465/AMR.1987.4306502

Mitchelmore, S., \& Rowley, J. (2010). Entrepreneurial competencies: a literature review and development agenda. International Journal of Entrepreneurial Behavior \& Research, 16(2), 92-111. https://doi.org/10.1108/13552551011026995

Morris, M. H., Webb, J. W., Fu, J., \& Singhal, S. (2013). A competency-based perspective on entrepreneurship education: Conceptual and empirical insights. Journal of Small Business Management, 51(3), 352-369. https://doi.org/10.1111/jsbm.12023

Nah, F. F.-H., Zeng, Q., Telaprolu, V. R., Ayyappa, A. P., \& Eschenbrenner, B. (2014). Gamification of Education: A Review of Literature. https://doi.org/10.1007/978-3-31907293-7_39

Neck, H. M., Greene, P. G., \& Brush, C. G. (2014). Teaching entrepreneurship: A practicebased approach. Edward Elgar Publishing

Neck, Heidi M., \& Corbett, A. C. (2018). The Scholarship of Teaching and Learning Entrepreneurship. Entrepreneurship Education and Pedagogy, 1(1), 8-41. https://doi.org/10.1177/2515127417737286

Neck, Heidi M., \& Greene, P. G. (2011). Entrepreneurship Education: Known Worlds and New Frontiers. Journal of Small Business Management, 49(1), 55-70. https://doi.org/10.1111/j.1540-627X.2010.00314.x

Nicholson, S. (2015). Peeking Behind the Locked Door: A Survey of Escape Room Facilities. Retrieved from http://scottnicholson.com/pubs/erfacwhite.pdf Nicholson, S. (2018). Creating Engaging Escape Rooms for the Classroom. Childhood Education, 94(1), 44-49. https://doi.org/10.1080/00094056.2018.1420363

O’Donovan, S., Gain, J., \& Marais, P. (2013). A Case Study in the Gamification of a University- 
level Games Development Course. https://doi.org/10.1145/2513456.2513469

RezaeiZadeh, M., Hogan, M., O’Reilly, J., Cunningham, J., \& Murphy, E. (2017). Core entrepreneurial competencies and their interdependencies: insights from a study of Irish and Iranian entrepreneurs, university students and academics. International Entrepreneurship and Management Journal, 13(1), 35-73. https://doi.org/10.1007/s11365-016-0390-y

Romero, M., Ott, M., \& Earp, J. (2012). Learning through playing for or against each other? Promoting collaborative learning in digital game based learning. ECIS 2012 Proceedings, Paper 93. Retrieved from https://www.researchgate.net/publication/235969273

Romme, A. G. L., \& Reymen, I. M. M. J. (2018). Entrepreneurship at the interface of design and science: Toward an inclusive framework. Journal of Business Venturing Insights, 10. https://doi.org/10.1016/j.jbvi.2018.e00094

Rosenkrantz, O., Jensen, T. W., Sarmasoglu, S., Madsen, S., Eberhard, K., Ersbøll, A. K., \& Dieckmann, P. (2019). Priming healthcare students on the importance of non-technical skills in healthcare: How to set up a medical escape room game experience. Medical Teacher, 41(11), 1285-1292. https://doi.org/10.1080/0142159X.2019.1636953

Salen, K., Tekinbas, K. S., \& Zimmerman, E. (2003). Rules of play: game design fundamentals. MIT press

Sarasvathy, S. D., Dew, N., Velamuri, S. R., \& Venkataraman, S. (2010). Three views of entrepreneurial opportunity. In Z. J. Acs \& D. B. Audretsch (Eds.), Handbook of entrepreneurship research (pp. 77-96). New York.: Springer.

Sarasvathy, S.D. (2001). Causation and Effectuation: Toward A Theoretical Shift From Economic Inevitability To Entrepreneurial Contingency. Academy of Management Review, 26(2), 243-263. https://doi.org/10.5465/AMR.2001.4378020 
Sarasvathy, Saras D., \& Dew, N. (2005). New market creation through transformation. Journal of Evolutionary Economics, 15(5), 533-565. https://doi.org/10.1007/s00191-005-0264-x

Sarasvathy, Saras D. (2003). Entrepreneurship as a science of the artificial. Journal of Economic Psychology, 24(2), 203-220. https://doi.org/10.1016/S0167-4870(02)00203-9

Schön, D. A. (2017). The reflective practitioner: How professionals think in action. In The Reflective Practitioner: How Professionals Think in Action. https://doi.org/10.4324/9781315237473

Shane, S., \& Venkataraman, S. (2000). The promise of entrepreneurship as a field of research. Academy of Management Review, 25(1), 217-226. https://doi.org/10.5465/AMR.2000.2791611

Shane, Scott, Locke, E. A., \& Collins, C. J. (2003). Entrepreneurial motivation. Human Resource Management Review, 13(2), 257-279. https://doi.org/10.1016/S10534822(03)00017-2

Short, J. C., Ketchen, D. J., Combs, J. G., \& Ireland, R. D. (2010). Research Methods in Entrepreneurship. Organizational Research Methods, 13(1), 6-15. https://doi.org/10.1177/1094428109342448

Smith, W. L., Schallenkamp, K., \& Eichholz, D. E. (2007). Entrepreneurial skills assessment: An exploratory study. International Journal of Management and Enterprise Development, 4(2), 179-201. https://doi.org/10.1504/IJMED.2007.011791

Strauss, A., \& Corbin, J. (1990). Basics of Qualitative Research: Grounded Theory Procedures and Techniques. Newbury Park, CA: SAGE Publications Inc.

Townsend, D. M., Hunt, R. A., McMullen, J. S., \& Sarasvathy, S. D. (2018). Uncertainty, Knowledge Problems, and Entrepreneurial Action. Academy of Management Annals, 12(2). 
https://doi.org/10.5465/annals.2016.0109

Veldkamp, A., van de Grint, L., Knippels, M., \& van Joolingen, W. (2020). Escape Education: A Systematic Review on Escape Rooms in Education. Preprints, (March), 1-19.

https://doi.org/10.20944/preprints202003.0182.v1

Vereniging Hogescholen. (2017a). Kennisbasis tweedegraadslerarenopleiding Economie. The Hague.

Vereniging Hogescholen. (2017b). Landelijk Opleidingsprofiel Bachelor Commerciële Economie 2018-2022.

Vincenti, W. (1990). What engineers know and how they know it. Retrieved from https://erta.pw/ nyly_pa_von_v_fazi.pdf

Vogel, J. J., Vogel, D. S., Cannon-Bowers, J., Bowers, C. A., Muse, K., \& Wright, M. (2006). Computer Gaming and Interactive Simulations for Learning: A Meta-Analysis. Journal of Educational Computing Research, 34(3), 229-243. https://doi.org/10.2190/FLHV-K4WAWPVQ-HOYM

Von Glasersfeld, E. (1987). Learning as a constructive activity. In J. Claude (Ed.), Problems of Representation in the Teaching and Learning of Mathematics. Lawrence Erlbaum; 1 edition.

Ward, T. B. (2004). Cognition, creativity, and entrepreneurship. Journal of Business Venturing, 19(2), 173-188. https://doi.org/10.1016/S0883-9026(03)00005-3

Weber, E. P., \& Khademian, A. M. (2008). Wicked Problems, Knowledge Challenges, and Collaborative Capacity Builders in Network Settings. Public Administration Review, 68(2), 334-349. https://doi.org/10.1111/j.1540-6210.2007.00866.x

Wiemker, M., Elumir, E., \& Clare, A. (2015). Escape Room Games: Can you transform an 
unpleasant situation into a pleasant one? Game Based Learning, 55.

Wiggins, B. E. (2016). An overview and study on the use of games, simulations, and gamification in higher education. International Journal of Game-Based Learning, 6(1), 1829. https://doi.org/10.4018/IJGBL.2016010102

Williams, P. (2018). Using escape room-like puzzles to teach undergraduate students effective and efficient group process skills. ISEC 2018 - Proceedings of the 8th IEEE Integrated STEM Education Conference, 2018-January, 254-257. https://doi.org/10.1109/ISECon.2018.8340495

Winkler, C. (2013). Toward a Dynamic Understanding of Entrepreneurship Education Research across the Campus - Social Cognition and Action Research. Entrepreneurship Research Journal, 4(1), 69-93. https://doi.org/10.1515/erj-2013-0039

Wouters, P., van Nimwegen, C., van Oostendorp, H., \& van der Spek, E. D. (2013). A metaanalysis of the cognitive and motivational effects of serious games. Journal of Educational Psychology, 105(2), 249-265.

Yin, R. K. (2009). Case study research: Design and methods (4th ed.). Thousand Oaks: Sage Publications. 